\title{
25 Research Square \\ Records of plutonium isotopes in marine sediments from the southern Gulf of Mexico
}

Jose A. Corcho Alvarado ( $\square$ jose.corcho@babs.admin.ch )

Spiez Laboratory: Labor Spiez https://orcid.org/0000-0002-4472-2756

Misael Diaz-Asenciuo

CICESE: Centro de Investigacion Cientifica y de Educacion Superior de Ensenada

Stefan Röllin

Spiez Labboratory: Labor Spiez

Juan Carlos Herguera

CICESE: Centro de Investigacion Cientifica y de Educacion Superior de Ensenada

\section{Research Article}

Keywords: Pu isotopes, Gulf of Mexico, sediments, Nevada Test Site fallout, Global fallout

Posted Date: September 17th, 2021

DOl: https://doi.org/10.21203/rs.3.rs-914393/v1

License: @ (i) This work is licensed under a Creative Commons Attribution 4.0 International License.

Read Full License 


\section{Abstract}

Here we report on new data on plutonium $(\mathrm{Pu})$ isotopes to elucidate activity concentrations, inventories, sources and their transport from the ocean surface to the sea floor from a collection of deep-sea sediment cores (depths ranging from 257 to $3739 \mathrm{~m}$ ) in the Gulf of Mexico (GoM). Sediment cores collected from the continental shelf and upper slope region of the GoM consistently showed ${ }^{240} \mathrm{Pu} /{ }^{239} \mathrm{Pu}$ ratios of 0.15 to 0.26 and Pu-inventories ranging from 15 to $35 \mathrm{~Bq} \mathrm{~m}^{-2}$. Inventories and ratios are consistent with global fallout Pu for this tropical region. In the continental shelf and upper slope regions, higher particle concentrations close to the margins favor significant scavenging and removal of Pu from the water column; in contrast with the deep-sea cores that show low ${ }^{240} \mathrm{Pu} /{ }^{239} \mathrm{Pu}$ ratios $(0.07-0.13)$ and a much lower Pu inventory ( $<7 \mathrm{~Bq} \mathrm{~m}-2$ ) implying a small fraction of the expected global fallout inventory has reached into the lower slopes and abyssal plain of the GoM. Low values and a progressive decrease of ${ }^{240} \mathrm{Pu} /{ }^{239} \mathrm{Pu}$ ratios and $\mathrm{Pu}$ inventories with increasing water depth have been previously reported for the GoM. The low Pu ratios indicate that Nevada tests fallout was an important source of Pu to deep-sea sediments, and that this source was likely more efficiently removed from the water column than global fallout Pu. Analysis of Pu isotopes in two sediment traps from the upper slope regions show ${ }^{240} \mathrm{Pu} /{ }^{239} \mathrm{Pu}$ ratios comparable to the ones observed in the global fallout. These results indicate that global fallout $\mathrm{Pu}$ is currently the main source of $\mathrm{Pu}$ in water column particles. Therefore, a significant fraction of global fallout Pu must still be present; either in a dissolved phase, or as biologically recycled material in the water column, or scavenged on the shelf and shelf break. Our results bring to light important questions on the application of $\mathrm{Pu}$ isotopes to establish sediment chronologies, since these radionuclides are shown to be tracers of bioturbation rather than accumulation processes in deep-sea sediments of the GoM, similar to previously reported results from excess ${ }^{210} \mathrm{~Pb}$.

\section{Highlights}

1. Analysis of Pu isotopes in deep-sea marine sediments in the GoM

2. Progressive decrease of $\mathrm{Pu}$ isotope ratios and inventories with increasing water depth

3. Global fallout Pu currently the main source of Pu in the water column

4. Significant fraction of global fallout Pu still present in the water column

5. Significant contribution of Pu from Nevada Testing Site in deep-sea sediments

6. Pu isotopes in deep sea sediments as tracers of bioturbation rather than accumulation processes

\section{Introduction}

The ecosystems in the Gulf of Mexico (GoM) are chronically exposed to hydrocarbons from natural seeps scattered throughout this region on top of which the occurrence of major oil spills from anthropogenic activities add a several fold amount of hydrocarbons on an annual timescale, such as the Ixtoc spill in 1979 (Jernelöv and Lindén 1981, Schwing, Machain-Castillo et al. 2021) or, more recently in 2010, the 
Deepwater Horizon (DWH) oil discharge (Joye, Teske et al. 2014, Brooks, Larson et al. 2015, Ziervogel, Joye et al. 2016). In the case of the DWH, a large though still not well constrained fraction of the total oil released was deposited in the deep-sea environment ( $1500 \mathrm{~m})$ (Brooks, Larson et al. 2015), and surprisingly in a brief period of time after the accident (Joye, Teske et al. 2014, Brooks, Larson et al. 2015, Ziervogel, Joye et al. 2016, Schwing, Machain-Castillo et al. 2021). Understanding of the impact of oil spills in the northern region of the GoM (shelf and upper slope environments) has increased in the last decade (GOMRI results) but is still limited in the southern deep-sea region of the GoM.

Sedimentary records provide proxy time series that may reveal clues to better understand the impact of past events. Obtaining proxy data from sedimentary records rely mainly on radiometric dating methods (e.g. ${ }^{14} \mathrm{C},{ }^{210} \mathrm{~Pb}$ ) (Yeager, Santschi et al. 2004, Corcho-Alvarado, Diaz-Asencio et al. 2014, Li, Li et al. 2021). For recent sediments (past $100 \mathrm{yrs}$ ), chronologies obtained using ${ }^{210} \mathrm{~Pb}$ has shown to be reliable in high sediment accumulation environments (Appleby and Oldfield 1978, Appleby and Oldfieldz 1983). However, the ${ }^{210} \mathrm{~Pb}$ ages may suffer from different biases and usually needs to be verified using an independent method (Appleby 1998, Santschi and Rowe 2008, Corcho-Alvarado, Diaz-Asencio et al. 2014, Barsanti, Garcia-Tenorio et al. 2020). For this purpose, other chronostratigraphic markers such as the global fallout radionuclides (e.g., ${ }^{137} \mathrm{Cs},{ }^{239,240} \mathrm{Pu}$ ) are commonly measured in sedimentary records (Appleby, Nolan et al. 1986, Appleby, Richardson et al. 1991, Díaz-Asencio, Corcho-Alvarado et al. 2016). Global fallout radionuclides are characterized by a distinct maximum in 1963, which is related to the period of higher intensity of nuclear weapons testing (Corcho-Alvarado, Diaz-Asencio et al. 2014). This fallout maximum (peak) can be identified in sedimentary records and further used as a time marker. Among the fallout radionuclides, plutonium $(\mathrm{Pu})$ isotopes have been found useful application in the GoM region (Scott, Salter et al. 1983, Buesseler and Sholkovitz 1987, Buesseler and Sholkovitz 1987, Oktay, Santschi et al. 2000, Yeager, Santschi et al. 2004, Corcho-Alvarado, Diaz-Asencio et al. 2014). ${ }^{137} \mathrm{Cs}$, another commonly used chronostratigraphic marker, is present at low or negligible levels in deep-sea sediments of the GoM (Yeager, Santschi et al. 2004, Corcho-Alvarado, Diaz-Asencio et al. 2014, CarneroBravo, Sanchez-Cabeza et al. 2018, Díaz-Asencio, Armenteros et al. 2020).

Pu isotopes in the GoM have two well-defined sources, global atmospheric fallout from nuclear weapon testing (direct fallout or continental runoff) and regional fallout from nuclear weapon testing in Nevada (USA) (Scott, Salter et al. 1983, Buesseler and Sholkovitz 1987, Oktay, Santschi et al. 2000). These two sources have distinct features that differentiate them. For example, in contrast to The integrated worldwide global fallout of ${ }^{240} \mathrm{Pu} /{ }^{239} \mathrm{Pu}$ isotope ratio has a characteristic for a mean value close to 0.18 (Kelley, Bond et al. 1999), in contrast to the regional derived Pu fallout from the Nevada Test Site (NTS) shows much lower mean ratios close to 0.035 (Hicks and Barr 1984, Buesseler and Sholkovitz 1987). Moreover, while global fallout is carried by small size particles of $1 \mu \mathrm{m}$ or less (Joseph, Gutafson et al. 1971), NTS fallout is transported by larger particles of 1 to $100 \mu \mathrm{m}$ diameter (Joseph, Gutafson et al. 1971). The particle size distribution and the chemical/physical form of the Pu-bearing fallout particles have important implications for the Pu geochemistry in the ocean (Buesseler and Sholkovitz 1987, Buesseler and Sholkovitz 1987, Buesseler 1997). Scott et al (1983) first hypothesized that material from 
the NTS was transported through the troposphere to the GoM, where it was removed to the sediments more effectively than other components of Pu fallout. Buesseler and Sholkovitz (1987) later showed that particles from the NTS fallout were rapidly removed to the sediments, accounting for over $40 \%$ of the Pu inventory in the Northwestern Atlantic. Global Pu fallout, on the other hand, accounted for most of the Pu in the water column and in shallow coastal sediments. Although these studies have shed some light on the fate of the Pu isotopes in the deep sediments of the GoM, the information is still limited.

This study focuses on further investigating the sources of Pu in deep sediments of the GoM and their main transport processes. The main objectives of the study were: i) to measure the Pu activities and ${ }^{240} \mathrm{Pu} /{ }^{239} \mathrm{Pu}$ atom ratios in sediment profiles and particle traps from the $\mathrm{GoM}$; ii) to evaluate the relative contributions of the global stratospheric fallout Pu and the regional tropospheric fallout Pu from the NTS to the deep-sea sediments of the GoM using a two-end-member mixing model; and iii) to propose a transport pathway of Pu fallout to the GoM. Another important objective of this work is to define the input functions of Pu to deep-sea sediments and to verify if these anthropogenic radionuclides can be used as a time marker for sedimentation studies. This information is important for other investigations being carried out in parallel, which are aimed at investigating the accumulation, degradation, and burial of organic matter, hydrocarbons and other contaminants in deep-sea regions of the GoM.

\section{Methods}

\subsection{Study location}

The GoM is a semi-enclosed oceanic basin flanked by two wide carbonate shelfs, located between the tropics and subtropics in the western Atlantic Ocean (Fig. 1). The region of our study in the southern GoM extends between the Sigsbee Abyssal Plain to the north, the Yucatan Shelf and Campeche Escarpment to the northeast and east, the Tamaulipas and Veracruz continental slopes to the west, and by the Campeche Saline Complex to the south (Fig. 1). The Florida and Campeche shelfs contribute with carbonate, and essentially very little siliciclastic sediments to the basin (Holmes 1976). Siliciclastic sediments input is mostly associated to several river systems, Mississippi-Atchafalaya system in the northern region, rivers carving the Eastern Sierra Madre to the west, and the Grijalva-Usumacinta river complex to the south. Most of these sediments are deposited on the continental shelf, and a fraction escapes the continental platform environments depositing on the continental slopes and an even smaller fraction reaches the abyssal plain (Brooks, Larson et al. 2015, Díaz-Asencio, Bartrina et al. 2019). Sediments beyond the shelf edge show a decreasing trend in the terrigenous components between the slopes and the abyssal plain (Morse and Beazley 2008, Díaz-Asencio, Bartrina et al. 2019).

\subsection{Sampling}

Two sediment cores collected in 2018 from the upper continental slope in the Campeche Saline Complex, and four sediment cores collected in 2019 from the lower continental slopes and the abyssal plain of the GoM are used in this study (see Table 1 and Fig. 1). The six sediment cores were retrieved using a Soutar 
box core $(40 \times 40 \mathrm{~cm})$, from which cores were subsampled on board using acrylic tubes (Internal diameter of $10 \mathrm{~cm}$ ). Core lengths generally varied between 20 and $35 \mathrm{~cm}$. Sediment cores were split along their depth axes, one-half was sectioned at $0.5 \mathrm{~cm}$ for geochemical and radionuclides analysis. Sediment samples were then frozen and later freeze-dried. 
Table 1

Pu inventory and mean ${ }^{240} \mathrm{Pu} /{ }^{239} \mathrm{Pu}$ isotope ratio in sediment cores from the GoM. The percentage of Pu delivered to each site by regional fallout from the NTS is also shown. For comparison, results from previous studies in the same region and in the North West Atlantic are also presented.

\begin{tabular}{|c|c|c|c|c|c|c|c|}
\hline Site & Depth & Location & & $\begin{array}{l}{ }^{240} \mathrm{Pu} /{ }^{239} \mathrm{Pu} \\
\text { isotope }\end{array}$ & $\begin{array}{l}\text { Total Pu } \\
\text { inventory }\end{array}$ & $\begin{array}{l}\text { NTS } \\
\text { Pu }\end{array}$ & $\begin{array}{l}\text { Global } \\
\text { fallout Pu }\end{array}$ \\
\hline & (m) & Lat. & Long. & ratio & $\left(\mathrm{Bq} \mathrm{m}^{-2}\right)$ & $(\%)$ & $\left(\mathrm{Bq} \mathrm{m}^{-2}\right)$ \\
\hline \multicolumn{8}{|c|}{ GoM (This study) } \\
\hline E36 & 257 & $18^{\circ} 46.1^{\prime} \mathrm{N}$ & $94^{\circ} 1.4^{\prime} \mathrm{W}$ & 0.17 & 33 & 10 & 30 \\
\hline E21 & 419 & $18^{\circ} 53.8^{\prime} \mathrm{N}$ & $94^{\circ} 7.0^{\prime} \mathrm{W}$ & 0.17 & 15 & 8 & 14 \\
\hline TS1 & 2417 & $21^{\circ} 0.5^{\prime} \mathrm{N}$ & $94^{\circ} 0.2^{\prime} \mathrm{W}$ & 0.09 & 7 & 53 & 3 \\
\hline F38 & 2822 & $27^{\circ} 59.9^{\prime} \mathrm{N}$ & $93^{\circ} 0.2^{\prime} \mathrm{W}$ & 0.09 & 5 & 51 & 2 \\
\hline A10 & 3340 & $26^{\circ} 0.6^{\prime} \mathrm{N}$ & $95^{\circ} 35.5^{\prime} \mathrm{W}$ & 0.11 & 9 & 41 & 5 \\
\hline $\mathrm{C} 23$ & 3739 & $24^{\circ} 59.4^{\prime} \mathrm{N}$ & $86^{\circ} 59.0^{\prime} \mathrm{W}$ & 0.11 & 1 & 55 & 1 \\
\hline \multicolumn{8}{|c|}{ GoM (Scott, Salter et al. 1983) } \\
\hline Station 9 & 106 & $28^{\circ} 44.0^{\prime} \mathrm{N}$ & $89^{\circ} 25.9^{\prime} \mathrm{W}$ & 0.19 & 410 & $<0$ & 410 \\
\hline Station 8 & 320 & $28^{\circ} 32.1^{\prime} \mathrm{N}$ & $89^{\circ} 17.7^{\prime} \mathrm{W}$ & 0.17 & 232 & 7 & 216 \\
\hline Station 7 & 786 & $28^{\circ} 21.6^{\prime} \mathrm{N}$ & $89^{\circ} 09.0^{\prime} \mathrm{W}$ & 0.14 & 13 & 28 & 10 \\
\hline Station 6 & 1701 & $27^{\circ} 57.5^{\prime} \mathrm{N}$ & $88^{\circ} 47.7^{\prime} \mathrm{W}$ & 0.14 & 5 & 29 & 4 \\
\hline Station 4 & 2744 & $26^{\circ} 34.0^{\prime} \mathrm{N}$ & $89^{\circ} 11.3^{\prime} \mathrm{W}$ & 0.11 & 7 & 51 & 3 \\
\hline Station 1 & 3402 & $23^{\circ} 43.9^{\prime} \mathrm{N}$ & $92^{\circ} 28.0^{\prime} \mathrm{W}$ & 0.10 & 5 & 54 & 2 \\
\hline Station 2 & 3649 & $23^{\circ} 57.1^{\prime} \mathrm{N}$ & $92^{\circ} 19.9^{\prime} \mathrm{W}$ & 0.10 & 5 & 56 & 2 \\
\hline \multicolumn{8}{|c|}{ North West Atlantic (Buesseler and Sholkovitz 1987) } \\
\hline A & 90 & $40^{\circ} 28.1^{\prime} \mathrm{N}$ & $70^{\circ} 54.1^{\prime} \mathrm{W}$ & 0.19 & 207 & $<0$ & 207 \\
\hline $\mathrm{F}$ & 501 & $39^{\circ} 55.1^{\prime} \mathrm{N}$ & $70^{\circ} 54.1^{\prime} \mathrm{W}$ & 0.18 & 44 & 3 & 43 \\
\hline $\mathrm{E}$ & 1275 & $39^{\circ} 48.1^{\prime} \mathrm{N}$ & $70^{\circ} 56.3^{\prime} \mathrm{W}$ & 0.15 & 38 & 19 & 31 \\
\hline D & 2362 & $39^{\circ} 35.0^{\prime} \mathrm{N}$ & $70^{\circ} 56.8^{\prime} \mathrm{W}$ & 0.14 & 21 & 30 & 15 \\
\hline $\mathrm{C}$ & 2700 & $39^{\circ} 10.3^{\prime} \mathrm{N}$ & $70^{\circ} 43.8^{\prime} \mathrm{W}$ & 0.13 & 5 & 36 & 3 \\
\hline G & 4469 & $31^{\circ} 54.1^{\prime} \mathrm{N}$ & $64^{\circ} 17.8^{\prime} \mathrm{W}$ & 0.10 & 4 & 54 & 2 \\
\hline $\mathrm{H}$ & 4990 & $36^{\circ} 27.9^{\prime} \mathrm{N}$ & $66^{\circ} 33.6^{\prime} \mathrm{W}$ & 0.11 & 7 & 52 & 3 \\
\hline
\end{tabular}


Two sediment traps (Parflux Mark78H-21, with a catchment area of $0.5 \mathrm{~m}^{2}$ and 21 collection cups of 0.5 L) were deployed in the western and southern slopes of the GoM (see Table 1 and Fig. 1). One of the traps was located in the western slope of the GoM (Perdido region), relatively close to land (ca.114 km) and at a water depth of $1130 \mathrm{~m}$ (55 m above the sea-floor sediments). The other trap was located in the Campeche Saline Complex slope, also relatively close to land (ca. $120 \mathrm{~km})$ and at a water depth of 1100 $\mathrm{m}$ (55 $\mathrm{m}$ above the seafloor). This region is located close to the Campeche Bay quasi-permanent cyclonic eddies (Pérez-Brunius, Furey et al. 2018) and periodically blanketed by sediments from the GrijalvaUsumacinta River system. Before deployment, each collection cup was filled with a hypersaline seawater solution prepared with filtered seawater, $\mathrm{Na}_{2} \mathrm{~B}_{4} \mathrm{O}_{7}, \mathrm{NaCl}$, and formaldehyde at $37 \%$ (to retard bacterial activity in the trap material). The period of collection for each cups in both traps lasted for 18 days. After sediment traps were recovered, samples were sieved through a $1000 \mu \mathrm{m}$ nylon screen to remove swimmers and large aggregates.

\subsection{Analyses}

Sediment samples were analyzed for Pu radioisotopes as described elsewhere (Röllin, Sahli et al. 2009, Sahli, Röllin et al. 2017, Röllin, Sahli et al. 2020). Briefly, about $5 \mathrm{~g}$ aliquots were spiked with known amounts of ${ }^{242} \mathrm{Pu}$ (about $3 \mathrm{pg}$ ). The aliquots were then digested by a borate fusion using $50 \mathrm{~mL} \mathrm{Pt} / \mathrm{Au}$ $(95 \% / 5 \%)$ crucibles in a furnace at $1100{ }^{\circ} \mathrm{C}$. The melt was poured into $4.5 \mathrm{M} \mathrm{HNO}_{3}$ and the silicates were precipitated with Poly-Ethylene Glycol (PEG) (Röllin et al. 2009). After filtration, Pu was separated from other radionuclides in a TEVA resin as described elsewhere (Sahli et al. 2017). Pu radioisotopes were analysed in a multi-collector inductively coupled plasma mass spectrometer (MC-ICP-MS) Neptune equipped with 9 Faraday collectors and five ion counters (SEM). Aqueous solutions were introduced in the MC-ICP-MS using a CETAC Arridus II desolvator (Elemental Scientific Inc.). All Pu isotopes were measured with the SEM detectors. Pu isotope concentrations were calculated from the signal of the ${ }^{242} \mathrm{Pu}$ tracer. The contributions of the Pu isotopes from the tracer and tailing from $\mathrm{U}$ and Th were corrected mathematically based on the isotope ratios from the certificate and abundance sensitivity measurements of $U$ and Th standards.

\subsection{Data interpretation}

We use a two-end-member mixing model to estimate the relative contribution of each Pu fallout source to the sediments in the GoM. The model is based on the distinct ${ }^{240} \mathrm{Pu} /{ }^{239} \mathrm{Pu}$ isotope ratios of the two sources of Pu: a) global fallout (GF) with a ratio of 0.18 , and b) regional tropospheric fallout from Nevada (NTS) with a ratio of 0.035 . The percentage of Nevada Pu fallout (\%NTS) in the sediments can be derived from the following equation:

$$
\% N T S=100 \bullet\left(\frac{R_{\text {sample }}-R_{G F}}{R_{N T S}-R_{G F}}\right)
$$


Where $R_{\text {sample }} R_{G F}$ and $R_{N T S}$ are the ${ }^{240} \mathrm{Pu} /{ }^{239} \mathrm{Pu}$ isotope ratios in the sample (measured), global fallout (0.18) and the NTS (0.035), respectively.

\section{Results And Discussion}

The plutonium analysis for sites E36, E21, TS1, F38, A10 and C23 are given in Table 1. The percentage of Pu delivered to each site by regional fallout from the NTS was calculated according to Eq. (1), and is listed in Table 1 along with the measured Pu inventory for each core. Sites located in the continental shelf and upper continental slope showed Pu inventories ( 15 to $33 \mathrm{~Bq} \mathrm{~m}^{-2}$, Table 1 and Fig. $2 \mathrm{~b}$ ) that are close to those expected from global fallout $\left(20-55 \mathrm{~Bq} \mathrm{~m}^{-2}\right.$ ) at these latitudes (Corcho-Alvarado, Diaz-Asencio et al. 2014). However, sediment cores collected from the abyssal plain and lower continental slope showed significantly lower ${ }^{239,240} \mathrm{Pu}$ inventories $\left(<7 \mathrm{~Bq} \mathrm{~m}^{-2}\right.$ ) (Fig. 2b). These deep-sea sites contain only a small fraction ( 1 to $5 \mathrm{~Bq} \mathrm{~m}^{-2}$, Table 1 ) of the expected Pu inventory from global fallout. These results are consistent with those reported by Scott et al (1983) and Yeager et al (2004), who observed equally low Pu inventories in abyssal sediments in the GoM (Scott, Salter et al. 1983, Yeager, Santschi et al. 2004). As has been observed elsewhere, deep ocean sediments commonly contain a fraction of the total global fallout Pu delivered to the ocean surface (Scott, Salter et al. 1983, Li, Guinasso et al. 1985, Nagaya and Nakamura 1993, Garcia-Orellana, Pates et al. 2009, Kinoshita, Sumi et al. 2011). Low Pu inventories has been further reported from abyssal sediments from the Venezuela Basin, in the Caribbean Sea ( $\mathrm{Li}$, Guinasso et al. 1985). Deep sediments from the North West Atlantic also contain Pu inventories lower than it would expected from global fallout (Buesseler and Sholkovitz 1987). The low Pu inventories in deep GoM sediments are thus not unusual.

It should be noted that Pu inventories in abyssal and lower continental slope sediments observed in this study are close to those reported by Scott et al. (1982) about 40 years earlier (Table 1, Fig. 2b). This is a strong indication that Pu transport from ocean water to deep-sea sediments over the past four decades has been very low or negligible. A large fraction of global fallout Pu is likely in the water column and/or has been horizontally transported to shallower sites where it might has been removed to the sediments. This points out that both Pu fallout components, NTS and global fallout, entered the deep sea sediments possible as a pulse like function, and not continuously, as it is usually observed in shallow coastal sites (Corcho-Alvarado, Diaz-Asencio et al. 2014, Carnero-Bravo, Sanchez-Cabeza et al. 2016, Carnero-Bravo, Sanchez-Cabeza et al. 2018). This is further supported by the little variability of the ${ }^{240} \mathrm{Pu} /{ }^{239} \mathrm{Pu}$ isotope ratios within each core (Fig. 3b, c).

Numerous studies have shown that global fallout Pu is mostly found in the ocean water column, concentrated at a given depth below the surface (Bowen, Noshkin et al. 1980, Buesseler 1997, Hirose, Kim et al. 2011, Kinoshita, Sumi et al. 2011, Rozmaric, Chamizo et al. 2021). In the Pacific Ocean, a pronounced subsurface maximum of Pu concentrations was first observed at depths varying between 250 to 750 m during a GEOSECS study in 1973/1974 (Bowen, Noshkin et al. 1980). Other studies in central south and tropical east Pacific similarly reported subsurface Pu maximums at depths of 500 to 
800 m (Povinec, Livingston et al. 2003, Hirose, Kim et al. 2011, Kinoshita, Sumi et al. 2011). In the Northwest Pacific, Pu time series in the water column showed that the subsurface Pu maximum was moving downward and getting smaller (Livingston, Povinec et al. 2001, Povinec, Livingston et al. 2003). Repeated sampling at the same location has shown that Pu subsurface maximum is indeed slowly moving downward at mean velocities of 3 to $17 \mathrm{~m} \mathrm{yr}^{-1}$ (Kinoshita, Sumi et al. 2011). A subsurface Pu maximum has been observed in other regions of the Pacific such as in the South China Sea and the Sulu Sea (Dong, Zheng et al. 2010), the Sea of Japan (Hirose, Miyao et al. 2002); and in other oceans such as in the Mediterranean Sea (Vintró, Mitchell et al. 1999, Fowler, Noshkin et al. 2000, Laissaoui, Benmansour et al. 2008), the northwest Atlantic (Cochran, Livingston et al. 1987); or the Benguela upwelling system in the southeast Atlantic (Rozmaric, Chamizo et al. 2021).

In deep-sea environments, Pu transport to bottom waters does occur. However, as sedimentation rate at such deep sites is extremely low (a few cm per 1000 yrs) (Garcia-Orellana, Pates et al. 2009, Carvalho, Oliveira et al. 2011), Pu in sediment is found at rather low levels (Li, Guinasso et al. 1985, Nagaya and Nakamura 1993, Garcia-Orellana, Pates et al. 2009). Inventories of deep-sea sediments in the tropical east Pacific Pu were up to 15 times lower than those found in the water column (Kinoshita, Sumi et al. 2011). In another study in the northern North Pacific Ocean, ${ }^{239,240} \mathrm{Pu}$ inventories in deep sediments were less than $20 \%$ of those found in the entire water column (Nagaya and Nakamura 1993). In the Mediterranean Sea, less than 3\% of the global fallout Pu deposited across the sea surface was found in deep sediments (Garcia-Orellana, Pates et al. 2009). Similarly, in the Venezuelan Basin (Caribbean Sea), sediments (depth: 3500 to $5050 \mathrm{~m}$ ) contained approximately $20 \%$ of the total Pu that has fallen to the ocean surface. All these studies evidence that a large fraction of global fallout Pu is still in the water column, and supported the existence of a subsurface maximum of Pu activity concentrations in most deep sites of our oceans. Unfortunately, no vertical profile of Pu in ocean water is available for the GoM. It is nonetheless not ruled out that such a subsurface Pu maximum is present in the water column of this gulf, as it has been suggested elsewhere (Scott, Salter et al. 1983). This conceptual model is represented in Fig. 4, where the relative importance of each Pu source in each depth section (Continental shelf, slope and abyssal plain) is represented.

The ${ }^{239,240} \mathrm{Pu}$ activity concentration and ${ }^{240} \mathrm{Pu} /{ }^{239} \mathrm{Pu}$ isotope ratio versus depth within each sediment core are plotted in Fig. 3. A common feature in all the investigated sites is that Pu penetration depth is found below $6 \mathrm{~cm}$, which is deeper than it would be expected from the low sedimentation accumulation rates of a few $\mathrm{cm}$ per $1000 \mathrm{yrs}$ reported for this region (Díaz-Asencio, Herguera et al. 2020). In cores from the abyssal plain and lower slope, Pu isotopes are found at 6 to $11 \mathrm{~cm}$ depth (Fig. 3a); while in the upper slope and continental shelf they are found slightly deeper at 12 to $19 \mathrm{~cm}$ depth (Fig. 3c). This is a strong indication that Pu profiles are primarily a result of mixing by bioturbation on the seafloor. This process is as well responsible for the little variability of the ${ }^{240} \mathrm{Pu} /{ }^{239} \mathrm{Pu}$ isotope ratio with depth within each core (Fig. 3b, d). Previous studies have shown the importance of bioturbation by benthic in deep-sea sediments of the GoM (Scott, Salter et al. 1983, Yeager, Santschi et al. 2004, Santschi and Rowe 2008, Díaz-Asencio, Herguera et al. 2020). Bioturbation is likely responsible for the not well defined peaks of 
${ }^{239,240} \mathrm{Pu}$ observed at approximately 2 to $3 \mathrm{~cm}$ depth in the cores E36, E21 and TS1 (Fig. 3a,c). These peaks are certainly not related to the global fallout maximum of 1963. The implication of this finding is that Pu works as a tracer of bioturbation rather than sediment accumulation in deep-sea sediments of this Gulf.

Based on the little variability of the ${ }^{240} \mathrm{Pu} /{ }^{239} \mathrm{Pu}$ ratio in the upper $8 \mathrm{~cm}$ of the sediment cores, a mean isotope ratio was calculated for each site and is reported in Table 1 . The mean ${ }^{240} \mathrm{Pu} /{ }^{239} \mathrm{Pu}$ ratio showed a consistent decrease with increasing water depths, from a ratio of 0.173 , at $257 \mathrm{~m}$ depth, to ratios close to 0.10 below $2000 \mathrm{~m}$ (Fig. 2a). These results are comparable to those previously reported from deep sediments from the GoM (Scott, Salter et al. 1983) and the North West Atlantic (Buesseler and Sholkovitz 1987).

Using Eq. (1), we estimated the percentage of NTS fallout Pu in each site. The results of these calculations are shown in Table 1. The percentage of Nevada derived Pu is higher in the abyssal and lower continental slope sediments than in the upper continental slope and shelf sediments. The decreasing trend of ${ }^{240} \mathrm{Pu} /{ }^{239} \mathrm{Pu}$ isotope ratios with increasing depths (Fig. 2a) implies a lower contribution of global fallout Pu at any given site in respect to the more rapidly deposited NTS fallout. Previous studies have shown that regional tropospheric fallout Pu from surface nuclear weapon tests is removed to the sediments more effectively than global fallout Pu (Buesseler and Sholkovitz 1987, Buesseler 1997, Povinec, Livingston et al. 2003, Dong, Zheng et al. 2010). In shallow water sediments close to the lithogenic input the high particle loads favor an enhanced Pu scavenging, and consequently the ${ }^{240} \mathrm{Pu} /{ }^{239} \mathrm{Pu}$ isotope ratio is controlled by the global fallout inputs $\left({ }^{240} \mathrm{Pu} /{ }^{239} \mathrm{Pu}\right.$ ratio close to 0.18 , Fig. 2a). In contrast to deep-sea waters where much lower particle loads control a low Pu scavenging (Scott, Salter et al. 1983, Buesseler and Sholkovitz 1987), and explain the lower NTS fallout signature $\left({ }^{240} \mathrm{Pu} /{ }^{239} \mathrm{Pu}\right.$ ratio close to 0.10 , Fig. 2a).

Results from particle traps deployed in the Perdido region and the Campeche Saline Complex show mean vertical particle fluxes in the water column of 105 and $119 \mathrm{~g} \mathrm{~m}^{-2} \mathrm{yr}^{-1}$, respectively. These particle fluxes fall within the range of those reported from the northern GoM (35 to $175 \mathrm{~g} \mathrm{~m}^{-2} \mathrm{yr}^{-1}$ ) (Giering, Yan et al. 2018). A mean ${ }^{240} \mathrm{Pu} /{ }^{239} \mathrm{Pu}$ isotope ratio of $0.17( \pm 0.02)$, consistent with the ratio observed in global fallout, was measured in bulk dry material collected at these two traps, implying that global fallout is the main source of Pu in the water column of the GoM.

The observed range of ${ }^{240} \mathrm{Pu} /{ }^{239} \mathrm{Pu}$ isotope ratios (0.09 to 0.11 ) in deep-sea sediments ( $>2000 \mathrm{~m}$ ) are remarkably comparable to those reported by Scott et al. (Scott, Salter et al. 1983), about four decades earlier. Considering that $\mathrm{Pu}$ in the water column shows ${ }^{240} \mathrm{Pu} /{ }^{239} \mathrm{Pu}$ ratios of 0.17 , the remarkably similar ratios of these two studies separated by 40 years argues against an additional deposition of global fallout Pu over the past four decades at these sites.

Our results further imply that $\mathrm{Pu}$ in deep-sea sediments of the GoM have entered as a pulse like function, and not continuously as it is usually observed in shallow sea sediments. Buesseler and Sholkovitz (1987) 
were the first to propose such an input in their interpretation of Pu isotopes in deep-sea sediments from the Northwestern Atlantic Ocean (Buesseler and Sholkovitz 1987). According to this model, significant inputs of regional fallout Pu from the NTS would be expected during the 1950s, when the most intensive atmospheric testing took place in Nevada. The second source of Pu, global fallout, started in the 1950s, had a maximum in 1962 and then decreased rapidly. For this source, a pulse input during 1960 can be assumed. These assumptions are in agreement with the findings from Oktay et al. (2004), who showed that Pu fallout from the NTS reached the Mississippi River Delta sediments during the early 1950s, while the global fallout maximum was identified at a shallower depth within the investigated core (Oktay, Santschi et al. 2000). These results have important implications for interpreting Pu isotopes in deep sea sediment and for investigating the transport of other contaminants such as large oil spills.

\section{Conclusions}

This study shows that Pu isotopes in deep-sea sediments in the GoM originated from two separate sources, on the one hand the regional fallout from the NTS and on the other the global stratospheric fallout. The results here reported on the distinct ${ }^{240} \mathrm{Pu} /{ }^{239} \mathrm{Pu}$ isotope ratio of these sources show that the relative contribution of the NTS to the total Pu in the sediments increases with depth, accounting for over $45 \%$ in the abyssal region. We do not find any significant deposition of Pu over the past four decades. These results further evidence that a pulse like input of Pu to the sediments is the most likely approximation for deep-sea sediments. Moreover, our results further support the model proposed by Scott et al (1983) for the deposition and transport of Pu in the GoM, implying that the vast majority of global fallout Pu still remains in the water column. The analysis of the ${ }^{240} \mathrm{Pu} /{ }^{239} \mathrm{Pu}$ isotope ratio in samples collected from two particle traps, located at about $1000 \mathrm{~m}$ depth, confirmed that global fallout is the largest source of $\mathrm{Pu}$ in the water column. Another implication of these results is the potential of $\mathrm{Pu}$ isotopes as tracers of bioturbation mixing rather than accumulation processes in deep-sea sediments.

\section{Declarations}

- Ethics approval and consent to participate: Not applicable

- Consent for publication: Not applicable

- Availability of data and materials:

All data generated or analysed during this study are included in this published article

- Competing interests: Not applicable

- Funding:

This study was conducted in the frame of the Project No. 201441 "Implementation of oceanographic observation networks (physical, geochemical, ecological) for the generation of scenarios in the case of possible contingencies related to the exploration and production of hydrocarbons in deep waters of the 
GoM" funded by the Hydrocarbon fund SENER-CONACYT (Mexico). This is a contribution of the GoM Research Consortium (CIGoM).

This study was also a result of the Research Contract No. 23493 "Radionuclides and Stable Isotopic determinations to understand the Organic Matter Cycle in sediments of Marine Ecosystems of the southern GoM", conducted in the frame of the IAEA Coordinate Research Program K41019 "Applied Radioecological Tracers to Assess Coastal and Marine Ecosystem Health"..

- Authors' contributions:

José A. Corcho-Alvarado, Misael Díaz-Asencio, Stefan Röllin, and Juan Carlos Herguera contributed to the study conception and design. Material preparation, data collection and analysis were performed by José A. Corcho-Alvarado, Misael Díaz-Asencio, Stefan Röllin, and Juan Carlos Herguera. José A. CorchoAlvarado wrote the first draft of the manuscript and José A. Corcho-Alvarado, Misael Díaz-Asencio, Stefan Röllin and Juan Carlos Herguera commented on previous versions of the manuscript. José A. CorchoAlvarado, Misael Díaz-Asencio, Stefan Röllin and Juan Carlos Herguera read and approved the final manuscript.

- Acknowledgements:

We thank Bertha Acosta, Yessica Contreras, Aideé Egremy Valdez, Gerardo Vallejo, Jose Abella, Ivonne Martinez, Abigail Pañola and Doreny Bobadilla for their help in sampling and preparing sediment cores. We are also grateful to the staff of the Nuclear Chemistry Division of Spiez Laboratory, an IAEA Collaborating Centre, for their support with the radionuclide analysis.

- Authors' information (optional)

\section{References}

Appleby PG (1998) Dating recent sediments by 210 Pb: problems and solutions. Finland: 7-24

Appleby PG, Nolan PJ, Gifford DW, Godfrey MJ, Oldfield F, Anderson NJ, Battarbee RW (1986) 210Pb dating by low background gamma counting. Hydrobiologia 143(1):21-27

Appleby PG, Oldfield F (1978) "The calculation of lead-210 dates assuming a constant rate of supply of unsupported $210 \mathrm{~Pb}$ to the sediment." CATENA 5(1): 1-8

Appleby PG, Oldfieldz F (1983) "The assessment of 210Pb data from sites with varying sediment accumulation rates. " Hydrobiologia 103(1):29-35

Appleby PG, Richardson N, Nolan PJ (1991) "241Am dating of lake sediments. " Hydrobiologia 214(1):35-42 
Barsanti M, Garcia-Tenorio R, Schirone A, Rozmaric M, Ruiz-Fernández AC, Sanchez-Cabeza JA, Delbono I, Conte F, De Oliveira JM, Godoy H, Heijnis M, Eriksson V, Hatje A, Laissaoui HQ, Nguyen E, Okuku SA, AlRousan S, Uddin MW, Yii, Osvath I (2020) Challenges and limitations of the 210Pb sediment dating method: Results from an IAEA modelling interlaboratory comparison exercise. Quat Geochronol 59:101093

Bowen VT, Noshkin VE, Livingston HD, Volchok HL (1980) Fallout radionuclides in the Pacific Ocean: Vertical and horizontal distributions, largely from GEOSECS stations. Earth Planetary Science Letters 49(2):411-434

Brooks GR, Larson RA, Schwing PT, Romero I, Moore C, Reichart G-J, Jilbert T, Chanton JP, Hastings DW, Overholt WA, Marks KP, Kostka JE, Holmes CW, Hollander D (2015) "Sedimentation Pulse in the NE Gulf of Mexico following the 2010 DWH Blowout". PLoS ONE 10(7):e0132341

Buesseler KO (1997) The isotopic signature of fallout plutonium in the North Pacific. J Environ Radioact $36(1): 69-83$

Buesseler KO, Sholkovitz ER (1987) The geochemistry of fallout plutonium in the North Atlantic: I. A pore water study in shelf, slope and deep-sea sediments. Geochim Cosmochim Acta 51(10):2605-2622

Buesseler KO, Sholkovitz ER (1987) The geochemistry of fallout plutonium in the North Atlantic: II. 240Pu239Pu ratios and their significance. Geochim Cosmochim Acta 51(10):2623-2637

Carnero-Bravo V, Sanchez-Cabeza J-A, Ruiz-Fernández AC, Merino-Ibarra M, Corcho-Alvarado JA, Sahli H, Hélie J-F, Preda M, Zavala-Hidalgo J, Díaz-Asencio M, Hillaire-Marcel C (2018) "Sea level rise sedimentary record and organic carbon fluxes in a low-lying tropical coastal ecosystem. " CATENA 162:421-430

Carnero-Bravo V, Sanchez-Cabeza J-A, Ruiz-Fernández AC, Merino-Ibarra M, Hillaire-Marcel C, CorchoAlvarado JA, Röllin S, Diaz-Asencio M, Cardoso-Mohedano J-G, Zavala-Hidalgo J (2016) Sedimentary records of recent sea level rise and acceleration in the Yucatan Peninsula. Science of The Total Environment 573:1063-1069

Carvalho FP, Oliveira JM, Soares AMM (2011) Sediment accumulation and bioturbation rates in the deep Northeast Atlantic determined by radiometric techniques. ICES J Mar Sci 68(3):427-435

Cochran JK, Livingston HD, Hirschberg DJ, Surprenant LD (1987) Natural and anthropogenic radionuclide distributions in the northwest Atlantic Ocean. Earth Planetary Science Letters 84(2):135-152

Corcho-Alvarado JA, Diaz-Asencio M, Froidevaux P, Bochud F, Alonso-Hernández CM, Sanchez-Cabeza JA (2014) "Dating young Holocene coastal sediments in tropical regions: Use of fallout 239,240Pu as alternative chronostratigraphic marker". Quat Geochronol 22(0):1-10

Díaz-Asencio M, Armenteros M, Corcho-Alvarado JA, Ruiz-Fernández AC, Sanchez-Cabeza J-A, MartínezSuárez A, Röllin S, Carnero-Bravo V (2020) "Coastal accretion and sea-level rise in the Cuban Archipelago 
obtained from sedimentary records". The Holocene 0(0):1-10

Díaz-Asencio M, Bartrina VF, Herguera JC (2019) "Sediment accumulation patterns on the slopes and abyssal plain of the southern Gulf of Mexico." Deep Sea Research Part I. Oceanographic Research Papers $146: 11-23$

Díaz-Asencio M, Corcho-Alvarado JA, Sánchez-Cabeza JA, Ruiz-Fernández AC, Eriksson M (2016) "Reconstruction of Recent Sedimentary Processes in a Carbonate Platform (Gulf of Batabano, Cuba) Using Environmental Radiotracers". Estuaries Coasts 39(4):1020-1034

Díaz-Asencio M, Herguera JC, Schwing PT, Larson RA, Brooks GR, Southon J, Rafter P (2020) "Sediment accumulation rates and vertical mixing of deep-sea sediments derived from $14 \mathrm{C}$ and $210 \mathrm{~Pb}$ in the southern Gulf of Mexico. " Marine Geology 429:106288

Dong W, Zheng J, Guo Q, Yamada M, Pan S (2010) Characterization of plutonium in deep-sea sediments of the Sulu and South China Seas. J Environ Radioact 101(8):622-629

Fowler SW, Noshkin VE, Jacques La R, Gastaud J (2000) "Temporal variations in plutonium and americium inventories and their relation to vertical transport in the northwestern Mediterranean Sea. " Limnology Oceanography 45(2):446-458

Garcia-Orellana J, Pates JM, Masqué P, Bruach JM, Sanchez-Cabeza JA (2009) "Distribution of artificial radionuclides in deep sediments of the Mediterranean Sea" Science of The Total Environment 407(2):887-898

Giering SLC, Yan B, Sweet J, Asper V, Diercks A, Chanton JP, Pitiranggon M, Passow U (2018) "The ecosystem baseline for particle flux in the Northern Gulf of Mexico." Elementa: Science of the Anthropocene 6

Hicks HG, Barr DW (1984) Nevada test site fallout atom ratios: 240Pu/239Pu and 241Pu/239Pu. United States: 5

Hirose K, Kim CS, Yim SA, Aoyama M, Fukasawa M, Komura K, Povinec PP, Sanchez-Cabeza JA (2011) Vertical profiles of plutonium in the central South Pacific. Prog Oceanogr 89(1):101-107

Hirose K, Miyao T, Aoyama M, Igarashisnm Y (2002) Plutonium isotopes in the Sea of Japan. J Radioanal Nucl Chem 252(2):293-299

Holmes CW (1976) Distribution, regional variation, and geochemical coherence of selected elements in the sediments of the central Gulf of Mexico. Professional Paper

Jernelöv A, Lindén $O$ (1981) "Ixtoc I: a case study of the world's largest oil spill." Ambio: 299-306 
Joseph A, Gutafson P, Russell I, SCHUERT A, Volchok H (1971) "Sources of radioactivity and their characteristics."

Joye SB, Teske AP, Kostka JE (2014) "Microbial Dynamics Following the Macondo Oil Well Blowout across. Gulf of Mexico Environments" BioScience 64(9):766-777

Kelley JM, Bond LA, Beasley TM (1999) "Global distribution of Pu isotopes and ${ }^{237} \mathrm{~Np}$ ". Sci Total Environ 237-238:483-500

Kinoshita N, Sumi T, Takimoto K, Nagaoka M, Yokoyama A, Nakanishi T (2011) "Anthropogenic Pu distribution in Tropical East Pacific" Science of The Total Environment 409(10):1889-1899

Laissaoui A, Benmansour M, Ziad N, Ibn Majah M, Abril JM, Mulsow S (2008) Anthropogenic radionuclides in the water column and a sediment core from the Alboran Sea: application to radiometric dating and reconstruction of historical water column radionuclide concentrations. J Paleolimnol 40(3):823-833

Li W, Li X, Mei X, Zhang F, Xu J, Liu C, Wei C, Liu Q (2021) A review of current and emerging approaches for Quaternary marine sediment dating. Science of The Total Environment 780:146522

Li WQ, Guinasso NL, Cole KH, Richardson MD, Johnson JW, Schink DR (1985) "Radionuclides as indicators of sedimentary processes in abyssal Caribbean sediments" Marine Geology 68(1):187-204

Livingston HD, Povinec PP, Ito T, Togawa $O$ (2001) The behaviour of plutonium in the Pacific Ocean. Radioactivity in the Environment. A. Kudo. Elsevier 1:267-292

Morse JW, Beazley MJ (2008) Organic matter in deepwater sediments of the Northern Gulf of Mexico and its relationship to the distribution of benthic organisms. Deep Sea Res Part II 55(24):2563-2571

Nagaya Y, Nakamura K. . Elsevier Oceanography Series. T. Teramoto (1993) Distributions and MassBalance of 239,240Pu and 137Cs in the Northern North Pacific. Elsevier 59:157-167

Oktay SD, Santschi PH, Moran JE, Sharma P (2000) "The 129iodine bomb pulse recorded in Mississippi River Delta sediments: results from isotopes of I, Pu, Cs, Pb, and C." Geochimica. et Cosmochimica Acta 64(6):989-996

Pérez-Brunius P, Furey H, Bower A, Hamilton P, Candela J, Garc?a-Carrillo P, Leben R (2018) Dominant Circulation Patterns of the Deep Gulf of Mexico. J Phys Oceanogr 48(3):511-529

Povinec PP, Livingston HD, Shima S, Aoyama M, Gastaud J, Goroncy I, Hirose K, Huynh-Ngoc L, Ikeuchi Y, Ito T, La Rosa J, Liong Wee Kwong L, Lee S-H, Moriya H, Mulsow S, Oregioni B, Pettersson H, Togawa 0 (2003) IAEA'97 expedition to the NW Pacific Ocean-results of oceanographic and radionuclide investigations of the water column. Deep Sea Res Part II 50(17):2607-2637 
Röllin S, Sahli H, Gnägi L, Alvarado JAC (2020) "Determination of plutonium and uranium radionuclides in glacier ice samples by MC-ICP-MS." CHIMIA 74 (1-6)(12)

Röllin S, Sahli H, Holzer R, Astner M, Burger M (2009) "Pu and Np analysis of soil and sediment samples with ICP-MS". Appl Radiat Isot 67(5):821-827

Rozmaric M, Chamizo E, Louw DC, López-Lora M, Blinova O, Levy I, Mudumbi B, van der Plas AK, Tenorio RG, McGinnity P, Osvath I (2021) "Fate of anthropogenic radionuclides (90Sr, 137Cs, 238Pu, 239Pu, $240 \mathrm{Pu}, 241 \mathrm{Am})$ in seawater in the northern Benguela upwelling system off Namibia." Chemosphere: 131514

Sahli H, Röllin S, Putyrskaya V, Klemt E, Balsiger B, Burger M, Corcho JA, Alvarado (2017) "A procedure for the sequential determination of radionuclides in soil and sediment samples. " Journal of Radioanalytical and Nuclear Chemistry

Santschi PH, Rowe GT (2008) "Radiocarbon-derived sedimentation rates in the Gulf of Mexico." Deep Sea Research Part II. Topical Studies in Oceanography 55(24):2572-2576

Schwing PT, Machain-Castillo ML, Brooks GR, Larson RA, Fillingham JN, Sanchez-Cabeza JA, RuizFernández AC, Hollander DJ (2021) "Multi-proxy assessment of recent regional-scale events recorded in Southern Gulf of Mexico sediments". Mar Geol 434:106434

Scott MR, Salter PF, Halverson JE (1983) Transport and deposition of plutonium in the ocean: evidence from Gulf of Mexico sediments. Earth Planetary Science Letters 63(2):202-222

Vintró LL, Mitchell PI, Condren OM, Downes AB, Papucci C, Delfanti R (1999) Vertical and horizontal fluxes of plutonium and americium in the western Mediterranean and the Strait of Gibraltar. Science of The Total Environment 237-238:77-91

Yeager KM, Santschi PH, Rowe GT (2004) "Sediment accumulation and radionuclide inventories $(239,240 \mathrm{Pu}, 210 \mathrm{~Pb}$ and $234 \mathrm{Th})$ in the northern Gulf of Mexico, as influenced by organic matter and macrofaunal density". Mar Chem 91(1):1-14

Ziervogel K, Joye SB, Arnosti C (2016) Microbial enzymatic activity and secondary production in sediments affected by the sedimentation pulse following the Deepwater Horizon oil spill. Deep Sea Res Part II 129:241-248

\section{Figures}




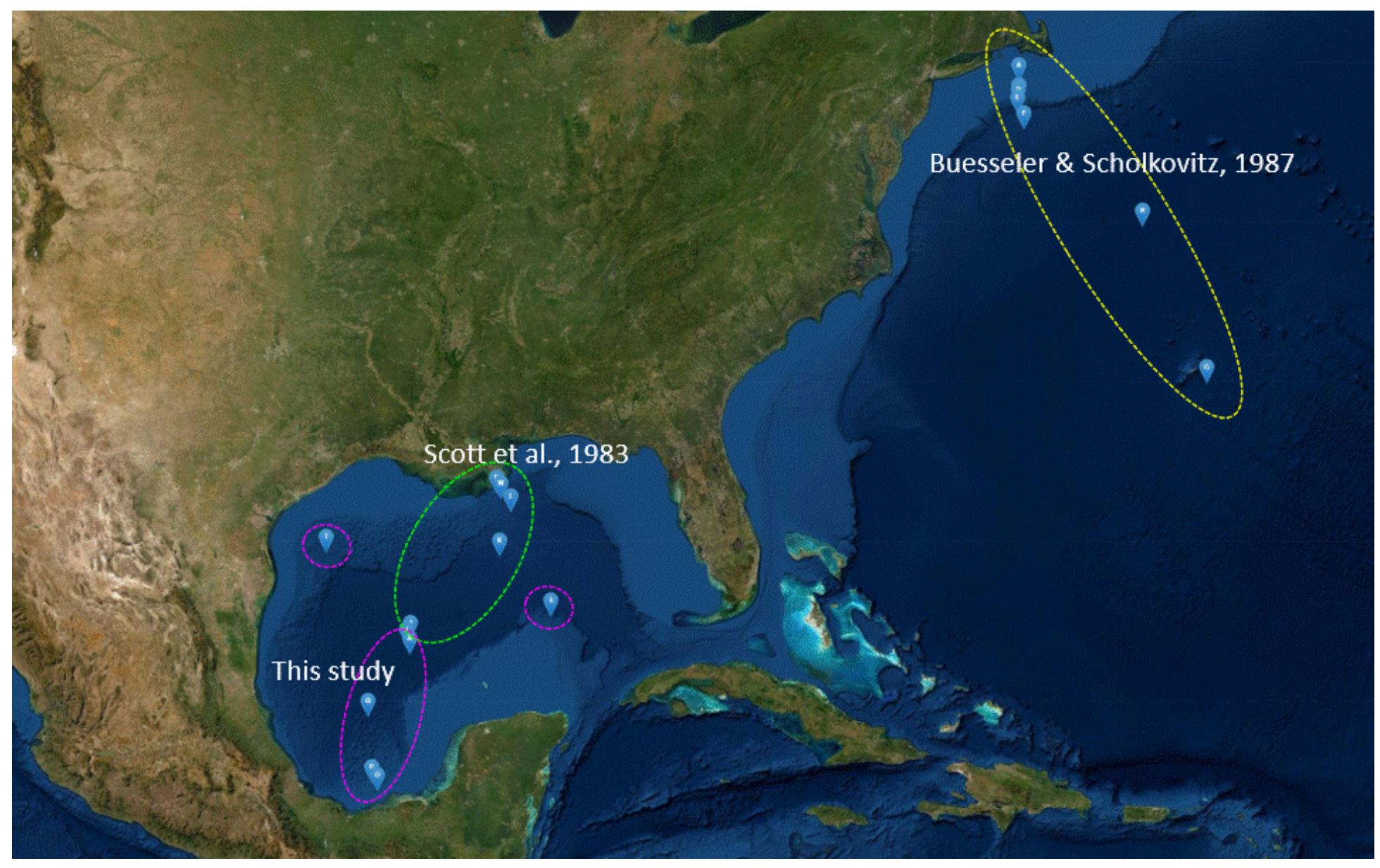

\section{Figure 1}

Location of the sampling sites investigated in this study (Magenta circles). The sites investigated in Scott et al. (1983) (Green circle), and Buesseler and Sholkovitz (1987) (Yellow circle) are also shown. 

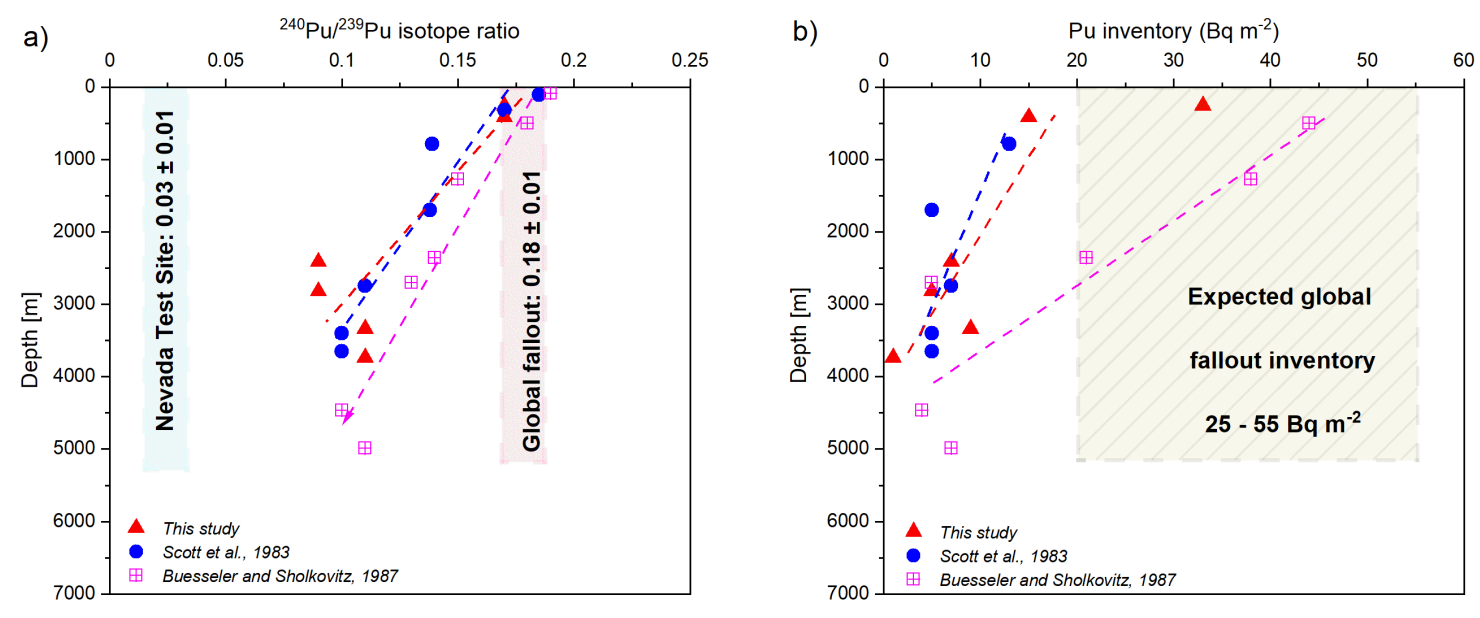

\section{Figure 2}

Relationship of the a) mean core 240Pu/239Pu isotope ratio and b) Pu inventory with the depth of the sampling site in the GoM. For comparison, the results reported by Scott et al. (1983) for the GoM, and the ones from Buesseler and Sholkovitz (1987) for the Western North Atlantic are also shown. 

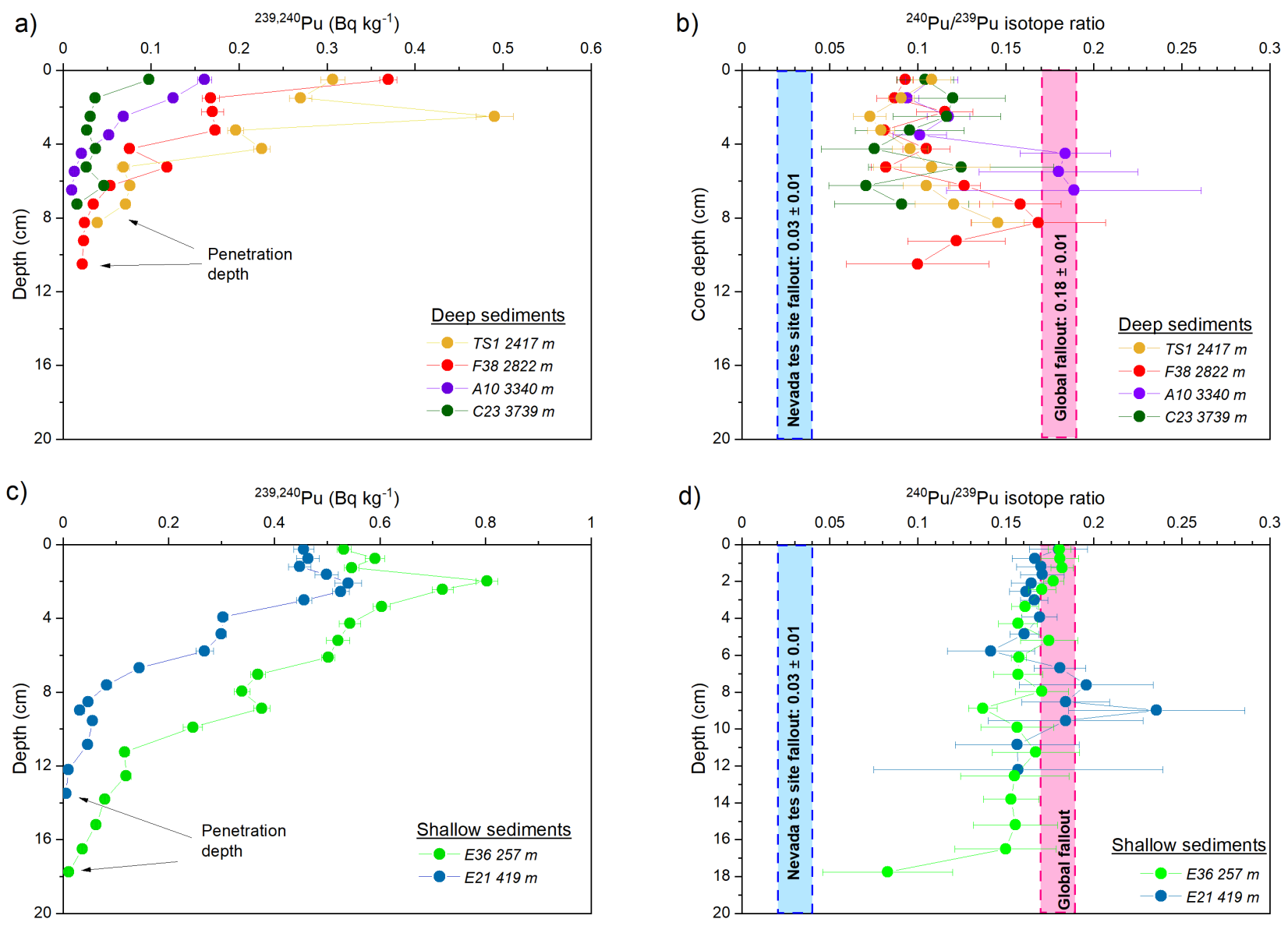

\section{Figure 3}

Profiles of 239,240Pu activity concentrations and 240Pu/239Pu isotope ratios in the sediment cores collected in the GoM. In order to gain visibility, shallow and deep cores are plotted in separate figures. 


\title{
Gulf of Mexico: Pu fallout and transport model
}

\author{
Global fallout \\ ${ }^{240} \mathrm{Pu} /{ }^{239} \mathrm{Pu}=0.18$ \\ Nevada fallout \\ ${ }^{240} \mathrm{Pu} /{ }^{239} \mathrm{Pu}=0.035$
}

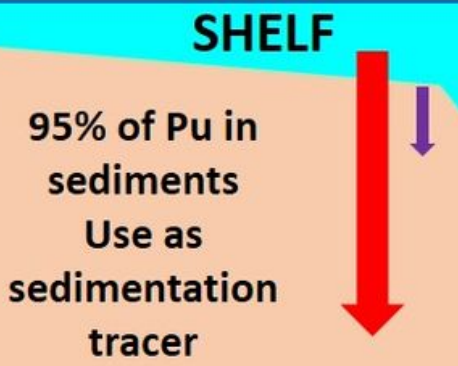

SLOPE

ABYSSAL

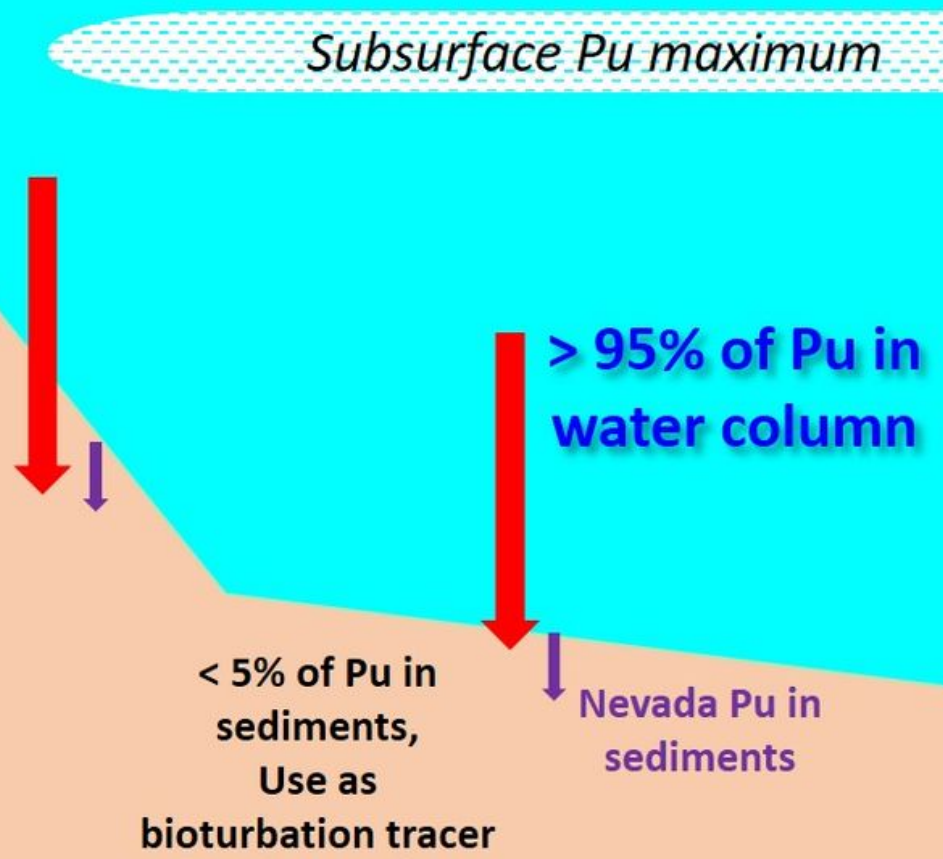

Figure 4

Conceptual model of Pu deposition and transport in the GoM (after (Buesseler and Sholkovitz 1987)). 